Article

\title{
CSR and Customer Outcomes: The Mediating Role of Customer Engagement
}

\author{
Moazzam Abbas *, Yongqiang Gao and Sayyed Sadaqat Hussain Shah \\ School of management, Huazhong University of Science and Technology, Wuhan 430074, China; \\ yqgao@hust.edu.cn (Y.G.); shah@hust.edu.cn (S.S.H.S.) \\ * Correspondence: moazzam109@hust.edu.cn; Tel.: +86-13247128113
}

Received: 20 October 2018; Accepted: 14 November 2018; Published: 16 November 2018

\begin{abstract}
Corporate social responsibility (CSR) image positively affects customer outcomes. Despite researchers' interest in the investigation of company favoring outcomes still, there is a need to further examine the psychological mechanisms that generate these outcomes. Customer engagement (CE) is a state of mind that drives customer behavior. The role of CE has been fully ignored in CSR literature. We suggest that CSR engenders $C E$ and examine the mediating role of CE between CSR and behavioral outcomes. A survey of 455 customers of banking services in Pakistan provided empirical evidence for hypothesis testing. Structural equation modeling was used to analyze the data. We find that CSR image induces CE that gives rise to behavioral responses i.e., customer loyalty, word-of-mouth (WOM) and customer feedback. This is the first study to examine the impact of CSR on customer feedback and to investigate the mediating role of CE.
\end{abstract}

Keywords: corporate social responsibility; customer engagement; customer loyalty; word-of-mouth; customer feedback

\section{Introduction}

Companies are very keen to enhance customer value. Customers exhibit various kinds of value added responses. It is a challenge for marketers to optimize the various kinds of favorable customer outcomes. In this regard, customer satisfaction is considered to be a prime objective to be achieved. Satisfaction is conceptualized as a level of fulfillment of expectations [1,2]. Marketers rely on satisfaction metrics to evaluate customer responses towards the company as satisfaction is believed to be associated with increased purchased intention, customer loyalty, profitability and market share [3-5]. Scholars focused on examining the antecedents and consequences of customer satisfaction. While studying the impact of corporate social responsibility (CSR) on customer outcomes, the role of satisfaction has been recognized and been given importance [6].

With the increasing competition and enhancing customer-company interactions, companies have realized the limitations of adopting just a satisfaction approach [7] and have expanded their view of customer management to developing a strong relationship with customers [8]. Companies moved to relationship marketing for customer value maximization. On one hand, expectations of customers are increasing. On the other hand, companies expect an extended role of customers in value creation [9]. Now, a customer is not viewed as a passive recipient of service. Service dominant logic assumes customer as a co-creator of value [10]. Customers share their valuable resources (time, knowledge, effort) with the company and other customers. Customers can play a role in new product development by giving suggestions, co-designing and helping in testing. Customers provide feedback and spread word-of-mouth (WOM). They can help other customers and can write reviews about the service on online platforms [11,12]. 
Companies can elicit positive customer outcomes by developing a solid relationship with the customers. The strength of the relationship can better be predicted by customer engagement (CE) [13]. $\mathrm{CE}$ is mental readiness to develop/maintain the relationship and adopt behaviors beneficial for the company [14]. It has become popularity among marketers. They use CE metrics to measure the level of engagement of their customers. The customer value can be measured more comprehensively with $\mathrm{CE}$ as compared to other customer outcomes [9]. It provides a more holistic view of customers [12]. CE can better predict the overall attitude of customers towards a company because it motivates customers for desirable outcomes while customer satisfaction is a hygiene factor [1]. The professional bodies like Nielson Media Research, Gallup, and Advertising Research Foundation are giving considerable attention to measuring CE [15]. It is a source of enhanced corporate performance. It provides the company with a superior competitive advantage [16] because engaged customers become agents of viral marketing by giving active recommendations. Practitioners realized the importance of $\mathrm{CE}$ before the researchers. The researchers started focusing on it one decade ago. In a survey in 2016, $58 \%$ executives claimed that their organizations had a formal CE program [17].

Business corporations control an enormous amount of resources and have a substantial impact on society. The responsible behavior of companies is necessary for the welfare of society and the companies recognize this fact and many of them incorporate CSR into their strategic objectives $[18,19]$. CSR is not a cost; it is an investment that generates various benefits for companies ranging from financial benefits to positive customer outcomes [20,21]. Customers are sensitive to social actions of companies. They appreciate the socially responsible behavior of a company and feel an obligation towards it. Customers feel a warmth towards the company and start championing it [22]. They like to associate themselves with the company because social values of their own and those of the company overlap with each other. Such a company is more appealing for customers and they consider it more credible and have positive feelings for the company [23-25]. They consider the company more reliable and like to interact and develop a relationship with it. This makes customers more engaged with the company $[26,27]$. Engaged customers feel a deep connection with the company and become more loyal and spread WOM [28,29]. Customers are more engaged with society friendly firms and they have the propensity to remain associated with them. They like to support the company and if they observe any deficiency in service or have any suggestion for improvement, they like to share it with the company instead of just switching to the other company carelessly. Thus, engaged customers are more likely to give feedback to the company as they want to support its improvement [30].

Despite the exponentially increasing importance of CE, it has been ignored in CSR literature. CSR plays an important role in relationship building with customers. CSR motivates customers to be attached to the company and adopt advocacy behavior. Karaosmanoglu [31] examined the impact of CSR on extra-role behavior but did not investigate the underlying processes. Influence of CSR on CE has not been studied to the best of our knowledge. Moreover, how CSR affects feedback intention has also not been studied yet. We examine how perceived CSR influences CE and how it gives rise to customer loyalty, WOM intention and feedback intention. This study provides three main contributions to literature. First, it studies how CSR affects CE. Second, we study the mediating role of $\mathrm{CE}$ in producing favorable customer outcomes i.e., customer loyalty, WOM intention and feedback intention. Third, we have included feedback intention in customer outcomes that has been ignored in CSR research studies. Feedback intention is a very important outcome in a dynamic environment of increasing competition and demanding innovation.

According to Gallup [32], engaged customers generate 37\% more revenue in retail banking than disengaged customers. Despite the high importance of CE in retail banking, there is a dearth of empirical studies in CE in the banking industry. Most of the research in CSR has been conducted in developed countries or high income developing countries like China. CSR awareness is increasing in developing countries and customers are appreciating it [31]. There is a need to conduct more research in CSR in middle income developing countries like Pakistan. Therefore, we preferred to conduct this study in the banking industry in Pakistan. 


\subsection{Theoretical Framework and Hypotheses}

Customers appreciate CSR efforts of a company and consider the company to be doing CSR on their behalf. They are psychologically connected to the company and positive feelings of attachment are evoked [33-35]. Customers' feeling of association with the company makes them engaged with the company. Engaged customers want to remain in the relationship and become more loyal to the company. They construe themselves as a member of the company and like to play a role for it and spread word of mouth. Engaged customers want the betterment of the company and want to experience its better services. Instead of switching, they want a solution if any problem with the service is generated. Thus, they are more likely to give feedback. Figure 1 shows the proposed model.

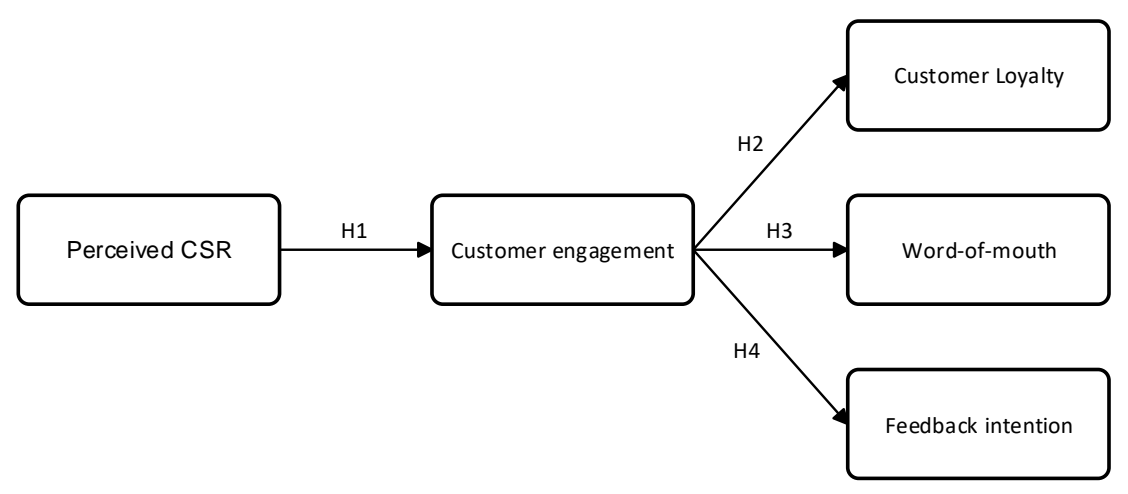

Figure 1. The proposed model.

\subsubsection{Customer Engagement}

Scholars have adopted two different approaches in the conceptualization of CE [36,37]. Some have taken a limited view of this phenomenon and have concentrated on behavioral dimension only and conceptualized it purely as a set of behaviors. Those taking a behavioral view have mostly used the term "customer engagement behaviors (CEBs)" [11,38,39]. Van Doorn [11] describe CEBs as the manifestation of behaviors that go beyond mere economic transactions. However, most of the scholars have taken the multidimensional view and describe $C E$ as a psychological state comprised of cognitive, emotional and behavioral dimensions [15,37,40-43]. According to Brodie [15], CE is a psychological state developed by interactive and cocreative experiences of a customer in the service relationship. Hollebeeke [44] describes it as a motivational state of mind with a certain level of cognitive, emotional and behavioral activity. Table 1 describes definitions of CE presented by different scholars.

Drawing on the domain of organizational psychology, Dwivedi [41] describes CE as a state of mind composed of vigor, dedication and absorption. Vigor refers to a customer's high energy interactions with the firm and his willingness to invest effort. Dedication depicts enthusiasm and inspiration. Absorption denotes that the customer is fully concentrated on, and happily engrossed in, interactions with the firm. 
Table 1. An overview: Customer engagement conceptualization.

\begin{tabular}{|c|c|c|c|}
\hline Author(s) & Definition & Reseach Type & Concept \\
\hline $\begin{array}{l}\text { Brodie et al., } \\
\text { (2011) [15] }\end{array}$ & $\begin{array}{l}\text { "a psychological state that occurs by virtue of } \\
\text { interactive, cocreative customer experiences with a } \\
\text { focal agent/object (e.g., a brand) in focal service } \\
\text { relationships" (p. 9) }\end{array}$ & conceptual & psychological \\
\hline $\begin{array}{l}\text { Dwivedi } \\
\text { (2015) [41] }\end{array}$ & $\begin{array}{l}\text { "positive,fulfilling, brand-use-related state of mind } \\
\text { that is characterized by vigor, dedication and } \\
\text { absorption" (p. 101) }\end{array}$ & empirical & psychological \\
\hline $\begin{array}{l}\text { Hollebeek } \\
\text { (2011) [44] }\end{array}$ & $\begin{array}{l}\text { "the level of an individual customer's } \\
\text { motivational, brand-related and } \\
\text { context-dependent state of mind" (p. 790) }\end{array}$ & conceptual & psychological \\
\hline $\begin{array}{l}\text { Jaakkola et al., } \\
\text { (2014) [39] }\end{array}$ & $\begin{array}{l}\text { "voluntary resource contributions that have a } \\
\text { brand or firm focus but go beyond what is } \\
\text { fundamental to transactions" (p. 248) }\end{array}$ & empirical & behavioral \\
\hline $\begin{array}{l}\text { Sashi (2012) } \\
\text { [45] }\end{array}$ & $\begin{array}{l}\text { "customer engagement occurs when customers } \\
\text { have strong emotional bonds in relational } \\
\text { exchanges with sellers" (p. 264) }\end{array}$ & conceptual & psychological \\
\hline $\begin{array}{l}\text { So et al., } \\
(2014)[42]\end{array}$ & $\begin{array}{l}\text { "a customer's personal connection to a brand as } \\
\text { manifested in cognitive, affective, and behavioral } \\
\text { actions outside of the purchase situation" (p. 310) }\end{array}$ & empirical & psychological \\
\hline $\begin{array}{l}\text { Van Doorn et } \\
\text { al., (2010) [11] }\end{array}$ & $\begin{array}{l}\text { "customer behavioral manifestations toward the } \\
\text { brand or firm, beyond purchase" (p. 253) }\end{array}$ & conceptual & behavioral \\
\hline $\begin{array}{l}\text { Vivek et al., } \\
\text { (2012) [43] }\end{array}$ & $\begin{array}{l}\text { "intensity of an individual's participation in and } \\
\text { connection with an organization's offerings or } \\
\text { organizational activities" (p. 133) }\end{array}$ & empirical & psychological \\
\hline
\end{tabular}

CE is a form of a strong customer-company relationship. Braun [37] argues that in CE customers maintain such close relationships with the organizations that they become endogenous to them. Service dominant logic [46] proposes that service is the unit of exchange and customers are always cocreators in the value creation process. It focuses on close customer-company relationships for creation of value. Based on this logic, Kumar [9] argues that $C E$ is necessary for value creation and customer life value is better represented by CE.

We consider CE as a psychological state because it is a broader concept than just manifestation of certain behaviors. It also encompasses cognitive and emotional responses [47]. CE is a state of mind that motivates customers to adopt company supporting behaviors. Behavioral outcomes (e.g., Loyalty, WOM, feedback intention) emerge from CE $[28,30]$. Taking CE as a broader concept is based on the logic that behavioral participation in engagement activities may not necessarily be on account of CE; rather, it may also have many other antecedents $[47,48]$ and engagement behaviors have high variability in different contexts [37,49]. Therefore, it is important to take a psychological view encompassing cognitive, emotional and behavioral aspects.

\subsubsection{Corporate Social Responsibility}

CSR describes the efforts of a company for the betterment of all stakeholders on a voluntary basis [50]. The role of companies is not limited to just economic benefits [51]. Companies perform welfare activities and it also gives benefits to companies. CSR gives rise to positive customer outcomes including purchase intention and loyalty [5,52]. One of the principal findings of CSR research is that customers seek to reward socially responsible companies [53]. Customers tend to appreciate their altruistic behavior [54]. Karaosmanoglu [31] demonstrate that CSR motivates customers to go beyond economic transactions and adopt extra role behavior. Romani [22] examine the fact that CSR generates advocacy behavior. Advocacy is believed to be closely associated with CE [45]. 
CSR attracts customers in many ways. When customers observe CSR initiatives of a company, they feel that the company is performing on their behalf and become emotionally attached to the company [33]. They believe that the objectives of the company and their own are the same. They like to be associated with the company and feel them as part of it considering the company and themselves as one entity [24]. CSR creates confidence in customers that the company will not exploit their interests [55] and they feel confident to develop a close relationship with the company. Thus, CSR makes customers more engaged by creating feelings of affection, oneness and trustworthiness.

Customers feel warm for socially responsible companies and become emotionally attached [33]. Customers feel that the benevolent company is acting on their behalf for the welfare of society and such feeling strengthens the emotional relationship with the company [34]. According to Liu [56], giving to others generates happiness. Romani [22] describes that when a company makes efforts for social causes, customers feel obliged to the company and they develop a positive emotion of gratitude and start championing the company. CSR efforts elicit feelings of pride also in customers [57]. Perez [5] do not focus on a specific emotion rather argue that customers develop overall positive emotions for socially responsible firms. Pansari [58] propose that emotional relationships play a key role in engendering CE. Engaged customers show behaviors that are in the favor of company. To show such behaviors, customers need affective feelings for the company. CE is a manifestation of emotional relationship [13]. Sashi [45] describes that emotional attachment evokes CE. According to Verleye [38], CE is a kind of love originating from affection. CSR initiatives give rise to CE by triggering affective feelings for the company.

According to social identity theory [59] and self-categorization theory [60], individuals categorize and identify them with those groups they find similar to their own-selves. The concept is applied to organizations also where customers identify them with the companies [55]. CSR image is recognized to have an integral role in signaling the identity of a company [61]. Customers want the betterment of society. When a company works for the welfare of society, there is an overlapping between the values of customers and the company. Customers start identifying themselves with the company [24]. The customers feel themselves as part of the company and they develop a feeling of we-ness. This feeling of we-ness instills a sense of emotional ownership in customers that is itself psychological engagement with the company $[27,30]$. The customers visualize the company and themselves as one entity and consider them as endogenous to it. They are more dedicated and absorbed to the company and like to keep themselves close to the company. Thus, CSR engages customers by giving the feeling of oneness $[11,26]$.

CSR creates a sense of belief that the company wants the well-being of all stakeholders and the company does not intend to exploit others [55]. Customers believe that the company has high reliability and integrity [62]. Connections with business organizations involve risk and uncertainty that hinder the strengthening of relationships. CSR reduces the risk by developing trust and customers become more willing to rely on the company and develop relationships. Morgan [63] presents commitment-trust theory of relationships and argues that feeling of trust in a company is a key to a strong relationship. Customers have reliability confidence in a socially benevolent company and feel safe in developing the relationship with it [8]. The customers become more open to the company. Van Doorn [11] argue that, if customers consider the company more reliable, they are more likely to exhibit engagement behavior. Bowden [1] describes CE as a psychological process and considers trust as a crucial element of this engagement process. Thus, CSR creates an environment that is suitable for strengthening relationships and engaging customers. The above discussion leads us to the following hypothesis.

Hypothesis 1 (H1). Perceived CSR influences customer engagement.

\subsubsection{Customer Loyalty}

Customer loyalty is the level of willingness of a customer to buy from a seller for a long time in the future [64]. Customer loyalty ensures the sustainable benefit of the company [65]. It predicts the 
long-term financial benefits. Value of $\mathrm{CE}$ depends on the customer outcomes it generates. Customer loyalty has central importance among outcomes of CE [1,15]. Engaged customers have a strong bond with the company and they adopt advocacy behavior and are less likely to switch. They value emotional ties over minor changes in offerings [41]. Engaged customers seek to maintain high interaction and strong connections with the company and are more loyal [66]. The customers concentrate more on the focal company and give less attention to competitors and their buying decisions remain unaffected by competitors' promotional campaigns and they remain loyal to the company $[26,28,43,67,68]$. Thus, we suggest the following hypothesis:

Hypothesis 2 (H2). Customer engagement influences customer loyalty.

\subsubsection{Word-of-Mouth}

Recommending the product to others is known as WOM and is an important behavioral expression of a strong relationship with the company. Engaged customers have enhanced interest in products/services of the company and like to discuss them with others [36]. CE persuades customers to advocate the company [69] and customers endeavor to improve the perception of the company and its services by telling others about the services [40]. Advancements in technology and expansion of social media have also facilitated customer-to-customer interactions. Engaged customers are more motivated and inclined to support the company. Recommending the services to others is a prominent manifestation of CE $[29,69]$. Engaged customers have more information about the products and they like to convey it. They are in a better position to refer the products/services to others [68]. Scholars have suggested a positive relationship between CE and WOM [70]. Thus, we hypothesize the following:

Hypothesis 3 (H3). Customer engagement influences word-of-mouth intention.

\subsubsection{Feedback Intention}

Customers' compliments/complaints and opinion about the products or services voiced to the company are termed as customer feedback [71]. Customers' likes and dislikes are crucial pieces of information for a company to be successful. Companies conduct marketing research to collect such information, but this cost of collecting information can be reduced if customers are motivated to provide their feedback voluntarily. Customer feedback confirms if what a company is doing is right or wrong [71]. Feedback gives a real insight into the problem if any exists and helps to improve the products according to expectations of the customers to gain a competitive advantage [72]. Customer feedback is the source of learning for the companies. It enhances organizational learning and management can make better decisions [73]. Feedback is a type of conversation that gives an opportunity to listen to the voice of customers [74]. It also indicates what customers know about the company and its services and this helps in making the communication strategy.

Literature of $\mathrm{CE}$ and co-creation has expanded the horizon of the concept of feedback. It is no longer limited to a complaining behavior; rather, it appraises customer needs or wants and level of satisfaction of customers [75]. Feedback is a behavioral manifestation of CE [11]. Engaged customers are emotionally attached and seek the betterment of the company and its services and are more ready to communicate their experiences [30]. Verleye [38] describes CE as a form of "love" that does not emerge from the transactional relationship but rather a customer's affection towards the company is a source of it. The customer becomes more supportive towards the company and is more likely to give feedback. Braun [37] argues that engaged customers are more likely to give constructive feedback, ideas and information. Kumar $[9,16]$ claims that engaged customers create value by actively giving feedback. Scholars have widely recognized that engaged customers are more willing to give feedback $[12,43]$. This leads to the following hypothesis:

Hypothesis 4 (H4). Customer engagement influences feedback intention. 


\section{Method}

\subsection{Sample and Procedure}

The objective of this study is to examine the effect of CSR on customer outcomes i.e., customer loyalty, WOM intention and feedback intention specifically through the mediating role of CE. We adopted a quantitative approach to test our hypotheses. Data were collected from individual customers of banks in Pakistan through a survey. In addition, 500 paper questionnaires were filled out by customers of 10 branch offices of five major banks in Pakistan. The survey was conducted in the first two weeks of July 2018 in Islamabad, the capital city of Pakistan. Customers visiting the branch offices were requested to fill out the survey, and they were told that participation was completely voluntary and information would remain anonymous. Customers were asked to visualize their main bank while responding to the questions. After removing responses with missing data and outliers, 455 responses were used in the analysis.

Furthermore, $268(59 \%)$ respondents were male and $187(41 \%)$ respondents were female. Our sample consisted of slightly more educated customers. In addition, $220(48.4 \%)$ respondents were graduates and higher degree holders. Respondents represented slightly younger customers as $405(89 \%)$ of them were below 50 years of age. The occupation of the higher number of respondents was administrative/managerial duties ( $n=151,33 \%)$ followed by professional $(n=96,21 \%)$ and self-employed $(n=81,18 \%)$, students $(n=78,17 \%)$ and others $(n=49,11 \%)$.

\subsection{Measurement}

Scales already existing in literature were used to measure all constructs. Perceived CSR was measured by using a four-item scale based on the paper by Stanaland [76]. CE was measured by a six-item scale used by Carvalho [36] originally developed by Dwivedi [41]. Customer loyalty was operationalized by four scaled items adopted from Martinez [55]. Customer feedback intention was measured by a three-item scale taken from Hsieh [30]. Three items for positive WOM were adopted from Romani [22,77]. Seven Likert scale ranging from 1 for strongly agree to 7 for strongly disagree was used for all five constructs. All measurement items used in our study are given in the Appendix A.

Data analysis was performed in three stages, i.e., measurement analysis, analysis of structural relationship and mediation analysis. The analysis was conducted by using Amos version 21 . Confirmatory factor analysis (CFA) was performed for the measurement model. Structural equation modeling (SEM) was used for estimation of the structural model. For determining the significance of indirect estimates, ( $t$-values and $p$-values) bootstrapping was performed (2000 subsamples).

\section{Results}

\subsection{Preliminary Analysis}

All the values of skewness and kurtosis were within range of \pm 1.5 , showing that data fulfills normality assumption. Twenty-one cases with Mahalanobis distance squared more than 0.5 were considered to be outliers and were removed [78], resulting in a final sample of 455. All inter-construct correlations were less than 0.8 , indicating that multicollinearity is not a problem in our data.

\subsection{Measurement Analysis}

CFA was performed for assessment of the measurement model. Results of CFA showed a good model fit $\left(\chi^{2}(158)=285,(p<0.001), \chi^{2} / d f=1.8\right.$, RMSEA $=0.042, G F I=0.94$, AGFI $=$ $0.92, N F I=0.96, T L I=0.98, C F I=0.98)$. Estimating parameters connecting construct and indicators assesses reliability and validity [79]. The values of Cronbash's alpha are more than 0.9 for all constructs indicating the high reliability of item scales used. All values of Composite reliability $(\mathrm{CR})$ are more than 0.85 and values of average variance extracted (AVE) are more than 0.65 as summarized in Table 2 . Values of composite reliability (CR) and average variance extracted (AVE) for all constructs are higher 
than the threshold values of 0.7 and 0.5 , respectively. All the standardized factor loadings are above 0.75 and are significant at $p<0.001$ confirming high convergent validity. Discriminant validity is confirmed by a Fornel-Larker criterion [80] that requires the values of square root of AVE to be higher than correlations among constructs. Table 3 exhibits that values of square root of AVE are higher than the standardized correlation of each construct with other constructs.

Common method bias was assessed by performing CFA with a single factor in which all items were loaded on a single factor. CFA with single factor represented worse model fit $\left(\chi^{2}(168)=\right.$ $2188,(p<0.001), \chi^{2} / d f=13$, RMSEA $=0.16$, GFI $=0.62$, AGFI $=0.5$, NFI $=0.71$, TLI $=$ $0.69, C F I=0.73)$. All these indicators of model fit are far beyond the acceptable limits. It shows that common method bias is not a problem in our data.

Table 2. Results of Confirmatory factor analysis.

\begin{tabular}{|c|c|c|c|c|c|}
\hline Latent Variable & Items & Loadings $(\beta)$ & Cronbach's $\alpha$ & CR & AVE \\
\hline \multirow{4}{*}{ Perceived CSR } & CSR1 & 0.86 & 0.90 & 0.89 & 0.68 \\
\hline & CSR2 & 0.85 & & & \\
\hline & CSR3 & 0.78 & & & \\
\hline & CSR4 & 0.80 & & & \\
\hline \multirow{6}{*}{ Customer engagement } & CE1 & 0.86 & 0.93 & 0.93 & 0.69 \\
\hline & CE2 & 0.77 & & & \\
\hline & CE3 & 0.83 & & & \\
\hline & CE4 & 0.86 & & & \\
\hline & CE5 & 0.78 & & & \\
\hline & CE6 & 0.87 & & & \\
\hline \multirow{4}{*}{ Customer Loyalty } & LY1 & 0.87 & 0.90 & 0.91 & 0.71 \\
\hline & LY2 & 0.83 & & & \\
\hline & LY3 & 0.82 & & & \\
\hline & LY4 & 0.86 & & & \\
\hline \multirow{3}{*}{ Word-of-mouth } & WOM1 & 0.86 & 0.92 & 0.93 & 0.81 \\
\hline & WOM2 & 0.90 & & & \\
\hline & WOM3 & 0.94 & & & \\
\hline \multirow{3}{*}{ Feedback intention } & FB1 & 0.86 & 0.91 & 0.90 & 0.74 \\
\hline & FB2 & 0.89 & & & \\
\hline & FB3 & 0.84 & & & \\
\hline
\end{tabular}

All standardized estimates $(\beta)$ are significant $(p<0.01)$.

Table 3. Correlation matrix with square root of AVE at the diagnol.

\begin{tabular}{lccccc}
\hline Latent Variable & $\mathbf{1}$ & $\mathbf{2}$ & $\mathbf{3}$ & $\mathbf{4}$ & $\mathbf{5}$ \\
\hline Perceived CSR & 0.82 & & & & \\
Customer engagement & 0.60 & 0.83 & & & \\
Customer loyalty & 0.67 & 0.71 & 0.84 & & \\
Word-of-mouth & 0.50 & 0.67 & 0.63 & 0.90 & \\
Feedback intention & 0.61 & 0.62 & 0.67 & 0.60 & 0.86 \\
\hline \multicolumn{2}{c}{ All estimates $(\beta)$ are significant $(p<0.001)}$.
\end{tabular}

\subsection{Estimation of Structural Relationship}

Structural model was examined by performing SEM. Perceived CSR was exogenous variable while $\mathrm{CE}$, customer loyalty, WOM intention and feedback intention were endogenous variables in the model. SEM analysis shows an acceptable model fit $\left(\chi^{2}(164)=438,(p<0.001), \chi^{2} / d f=2.6\right.$, RMSEA $=$ $0.061, G F I=0.91, A G F I=0.88, N F I=0.94, T L I=0.96, C F I=0.96)$. Table 4 indicates the results of hypotheses testing. Perceived CSR gives rise to CE. Impact of CSR on CE is considerably high $(\beta=0.64, p<0.001)$, providing evidence for support of Hypothesis 1. CE has been found to be closely related with customer loyalty $(\beta=0.75, p<0.001)$ and $\mathrm{H} 2$ is accepted. $\mathrm{CE}$ has a positive influence on 
WOM intention $(\beta=0.7, p<0.001)$ and $\mathrm{H} 3$ is supported. $\mathrm{CE}$ has a positive relation with feedback intention $(\beta=0.67, p<0.001)$ and $\mathrm{H} 4$ is supported. Figure 2 demonstrates the structural relationship.

Table 4. Results of SEM.

\begin{tabular}{lccc}
\hline Relationship of Variables & Hypotheses & $\boldsymbol{\beta}$ & Test Result \\
\hline Perceived CSR-Customer engagement & H1 & 0.64 & supported \\
Customer engagement-Customer loyalty & H2 & 0.75 & supported \\
Customer engagement-Word-of-mouth & H3 & 0.70 & supported \\
Customer engagement-Feedback intention & H4 & 0.67 & supported \\
\hline
\end{tabular}

All estimates $(\beta)$ are significant $(p<0.001)$.

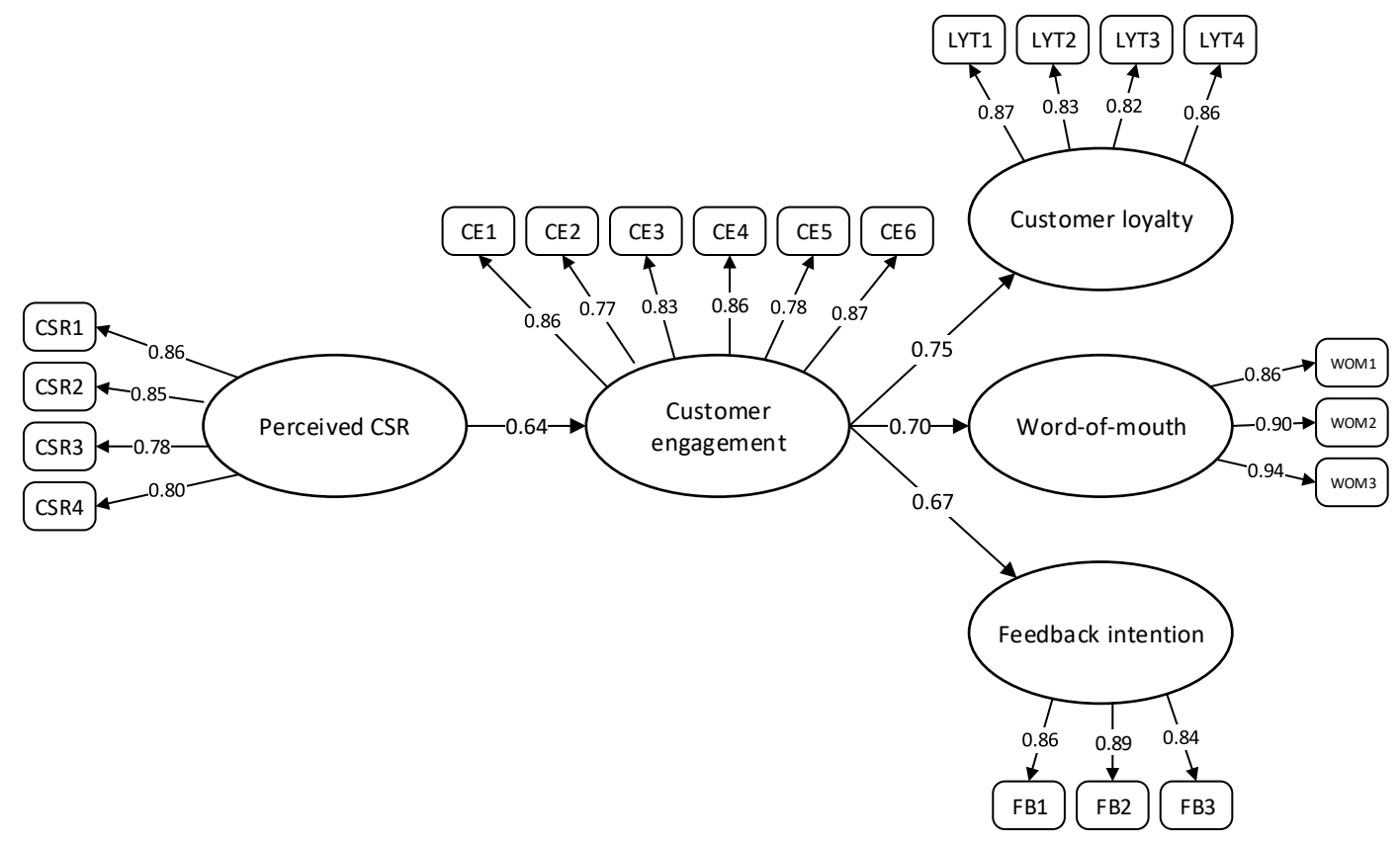

Figure 2. Structural model.

\subsubsection{Indirect Effects}

We theorize that CSR engenders CE which further generates customer outcomes i.e., loyalty, WOM and feedback intention. To confirm this, it is important to analyze the indirect effects of CSR on these outcomes. We found that CSR had a considerable impact on customer outcomes through CE as shown in Table 5. Analyzing the significance of indirect estimates is also important because sometimes direct paths are significant but overall indirect paths are not significant. We used bootstrapping for this purpose and found that all indirect paths were significant at $p=0.001$. The impact of CSR on feedback intention has been ignored in CSR literature; however, our findings show that CSR explains $15 \%$ variability in customer feedback intention $(\beta=0.39, p<0.001)$. CSR has been found to have a strong indirect impact on customer loyalty $(\beta=0.43, p<0.001)$ and also WOM intention $(\beta=0.45, p<0.001)$.

Table 5. Indirect effects.

\begin{tabular}{lc}
\hline Relationship of Variables & $\boldsymbol{\beta}$ \\
\hline Perceived CSR-Customer engagement-Customer loyalty & 0.43 \\
Perceived CSR-Customer engagement-Word-of-mouth & 0.45 \\
Perceived CSR-Customer engagement-Feedback intention & 0.39 \\
\hline \multicolumn{2}{c}{ All estimates $(\beta)$ are significant $(p<0.001)}$.
\end{tabular}




\subsubsection{Mediation Analysis}

For assessment of mediation effect, direct paths from CSR to customer outcomes were drawn in our structural model and the direct estimates were determined. All estimates for direct paths from CSR to customer outcomes i.e., loyalty, WOM and feedback were significant. Then, we ran another model without mediation of CE and estimated the direct effects of CSR on customer outcomes and compared the estimates of models with and without mediation. Results show that the direct effect of CSR on feedback intention is $\beta=0.68(p<0.001)$, but, after mediation, it is reduced to $\beta=0.38$. Although there is a reduction in estimate of direct path after mediation but significance of estimates can confirm any kind of mediation. We find that the direct impact of CSR on feedback is reduced after mediation, but it is still significant $(p<0.001)$. As the direct path is reduced but still remains significant, it indicates the existence of partial mediation.

A similarly direct effect of CSR on customer loyalty is $\beta=0.73(p<0.001)$, but it is reduced to $\beta=0.38(p<0.001)$ after mediation and direct effect of CSR on WOM intention is $\beta=0.58(p<0.001)$ that is reduced to $\beta=0.17(p<0.001)$ after mediation representing partial mediation of CE. Mediation analysis exhibits that $\mathrm{CE}$ is an important mediator and plays a key role in generating customer outcomes from CSR.

\section{Discussion and Implications}

Bhattacharya [81] suggest that, in order to understand the impact of CSR on customer outcomes with any degree of precision, it is important to investigate the underlying processes. Studies in CSR literature have concentrated their attention on trust, identification, company evaluation and satisfaction in underlying processes. They mainly focused on cognitive factors and attention towards affective responses of customer remained limited. In this study, we adopted a more holistic approach by examining the role of $\mathrm{CE}$ that is a state of mind and it is a broader concept with cognitive, emotional and behavioral dimensions.

We found that perceived CSR had a positive impact on CE. Our finding is consistent with previous studies that suggest that CSR engenders emotional attachment with the company and customers feel themselves as part of it. They consider the company as a reliable partner and develop positive feelings for the company $[5,22,33]$ and their dedication towards the company is increased and they become more engaged. We find that CSR evokes behaviors in customers that go beyond economic transactions and CE plays a vital role in developing those behaviors. Our results exhibit that CE mediates the effect of CSR on customer loyalty, WOM intention and feedback intention. Impact of CSR on feedback intention that was previously ignored has been investigated in our study and it demonstrates that CSR has a considerable indirect impact on feedback intention, and this outcome is in line with the existing research [22,31] that CSR elicits advocacy or supporting behavior. Customers are motivated to give suggestions to socially responsible firms in order to play a part in their success.

CSR is helpful in increasing customer loyalty and CE plays a key role in engendering loyalty. Loyalty is one of the major outcomes of $\mathrm{CE}$ and is highly valuable for businesses as loyal customers ensure the sustainable sales. In addition to customer loyalty, WOM is also an important outcome of CSR that attracts new customers and is considered a reliable and impartial source of information among customers. Engaged customers are more inclined to spread WOM.

Our findings have important implications for corporations, especially in the banking and service industry. CSR is an important strategic tool that gives rise to positive customer outcomes including customer loyalty, WOM and feedback intention. CE is already popular among practitioners. Growing market competition, technological advancements and social media have made relationship marketing essential for value generation. $\mathrm{CE}$ is associated with the expansion of revenues [16]. Realizing the importance of it, marketers are keen to find ways to engage customers. Customers can be motivated to contribute to marketing functions [12]. We suggest that customers can be engaged by developing an ethical image. Perceived CSR motivates customers to engage with the company. CSR initiatives that appeal to the emotional feelings of customers are more effective in inducing engagement. The affective 
aspect of CSR is responsible for the engagement of customers. CSR practices that portray the image of companies congruent with the personality of customers are more advantageous.

Synchronization of CSR and engagement strategies will be more effective in developing a strong relationship with customers and engendering engagement. CSR communication can play a crucial role. CSR communication strategy should be formulated to drive customers to identify themselves with the company. Engaged customers give WOM recommendations. Organizations should try to enhance the knowledge of the customers as efficacious customers spread WOM more confidently. CSR enhances feedback intention; however, managers should try to facilitate and enhance the interactions to encourage customers.

\section{Limitations}

Our results contribute important insights into CSR and marketing literature. However, there are certain limitations of our study that indicate paths for future investigations. The study was carried out in the banking industry. To make its findings more generalized, future research may use data collected from various industries and for various products to assess the customers' responses to CSR. We conducted the study in Pakistan, which is a developing country. The study is required to be replicated in developed countries.

We studied the influence of CSR image on CE in general, and it is important to investigate the impact of socially responsible initiatives on CE in specific settings like engagement in social media activities or other online platforms run by a company. We measured CE on a self-reporting scale; however, more objective measures can be applied by operationalizing it differently in future studies. We have used a first order single construct based on six items to measure $\mathrm{CE}$, and higher order construct can be used in future.

We considered only the impact of positive CSR image on CE, but the impact of negative attribution of CSR on CE is yet to be probed. We treated CSR as one construct while CSR literature provides evidence of multidimensionality [82]. It can be explored further whether certain dimensions of CSR (e.g., environmental and social) can influence CE more than the others. The moderating role of various factors not included in our study like product quality, industry and brand value can be important to affect CE [58].

\section{Conclusions}

Socially responsible behavior of companies is about caring about all of its stakeholders, which not only gives benefits to stakeholders but is also paid back to companies in the form of positive customer outcomes. The effects of CSR on customers are not limited to just purchasing decisions. CSR affects overall attitude and behavior of customers. CSR creates positive feelings and customers feel the company as an extension of the self and become more engaged in socially benevolent companies. $\mathrm{CE}$ further gives rise to favorable customer responses. Engaged customers have strong ties with the company and are more loyal to it. They are more motivated to give WOM recommendations. CSR provides the company with valuable information also by enhancing customers' feedback intentions, and CE plays an important role in this. Engaged customers want the betterment of the company and adopt company supporting behaviors.

Author Contributions: M.A. and Y.G. conceived and developed conceptual framework; M.A. and S.S.H.S. conducted the survey and analyzed the data; Y.G. and S.S.H.S investigated and interpreted the results; M.A. wrote the paper; All authors contributed to the final manuscript.

Funding: The authors received no funding for this research.

Acknowledgments: We would like to express great appreciation to Khurram Chouhan and Aneela sahar Fatima for their support for collecting data. We are very grateful to Mirza Nauman for his valuable suggestions and help.

Conflicts of Interest: The authors declare no conflict of interest. 


\section{Appendix A. Measurement Items}

\section{Perceived CSR [76]}

1. The bank is committed to well-defined ethics principles.

2. The bank ensures that their employees act in a legal manner.

3. The bank plans for their long-term success as well as society's.

4. The bank plays a role in our society that goes beyond the mere generation of profits.

\section{Customer engagement $[36,41]$}

1. I am passionate about using the bank's services.

2. I can continue using the bank's services for very long periods.

3. I feel enthusiastic when interacting with the bank.

4. I am proud of the bank.

5. I get absorbed when I interact with the bank.

6. I feel happy when I am interacting with the bank.

\section{Customer loyalty [55]}

1. I use the bank as my first choice compared to other banks.

2. It would be costly in terms of money, time and effort to end the relationship with the bank.

3. I shall continue considering this bank as my main bank in the next few years.

4. I would recommend the bank if somebody asked my advice.

\section{Word-of-mouth [22,77]}

1. I say positive things about the bank to others.

2. I recommend the services of the bank to friends, relatives and other people.

3. I mention favorable things of the bank to fiends, relatives and other people.

\section{Feedback intention [30]}

1. I fill out customer satisfaction surveys to the bank.

2. I provide helpful feedback to the bank to improve the services.

3. I inform the bank about the great usage experience I have received as an individual member.

\section{References}

1. Bowden, J.L.H. The process of customer engagement: A conceptual framework. J. Market. Theory Pract. 2009, 17, 63-74. [CrossRef]

2. Cronin, J.J., Jr.; Brady, M.K.; Hult, G.T.M. Assessing the effects of quality, value, and customer satisfaction on consumer behavioral intentions in service environments. J. Retail. 2000, 76, 193-218. [CrossRef]

3. Kennedy, M.S.; Ferrell, L.K.; LeClair, D.T. Consumers' trust of salesperson and manufacturer: An empirical study. J. Bus. Res. 2001, 51, 73-86. [CrossRef]

4. Anderson, E.W.; Mittal, V. Strengthening the satisfaction-profit chain. J. Serv. Res. 2000, 3, 107-120. [CrossRef]

5. Pérez, A.; Del Bosque, I.R. An integrative framework to understand how CSR affects customer loyalty through identification, emotions and satisfaction. J. Bus. Ethics 2015, 129, 571-584. [CrossRef]

6. Luo, X.; Bhattacharya, C.B. Corporate social responsibility, customer satisfaction, and market value. J. Market. 2006, 70, 1-18. [CrossRef]

7. Bennett, R.; Rundle-Thiele, S. Customer satisfaction should not be the only goal. J. Serv. Market. 2004, 18, 514-523. [CrossRef]

8. Palmatier, R.W.; Dant, R.P.; Grewal, D.; Evans, K.R. Factors influencing the effectiveness of relationship marketing: A meta-analysis. J. Market. 2006, 70, 136-153. [CrossRef] 
9. Kumar, V.; Aksoy, L.; Donkers, B.; Venkatesan, R.; Wiesel, T.; Tillmanns, S. Undervalued or overvalued customers: capturing total customer engagement value. J. Serv. Res. 2010, 13, 297-310. [CrossRef]

10. Vargo, S.L.; Lusch, R.F. Evolving to a new dominant logic for marketing. J. Market. 2004, 68, 1-17. [CrossRef]

11. Van Doorn, J.; Lemon, K.N.; Mittal, V.; Nass, S.; Pick, D.; Pirner, P.; Verhoef, P.C. Customer engagement behavior: Theoretical foundations and research directions. J. Serv. Res. 2010, 13, 253-266. [CrossRef]

12. Harmeling, C.M.; Moffett, J.W.; Arnold, M.J.; Carlson, B.D. Toward a theory of customer engagement marketing. J. Acad. Market. Sci. 2017, 45, 312-335. [CrossRef]

13. Zainol, Z.; Omar, N.A.; Osman, J.; Habidin, N.F. The Effect of Customer-Brand Relationship Investments' Dimensions on Customer Engagement in Emerging Markets. J. Relationsh. Market. 2016, 15, 172-199. [CrossRef]

14. Dessart, L.; Veloutsou, C.; Morgan-Thomas, A. Capturing consumer engagement: duality, dimensionality and measurement. J. Market. Manag. 2016, 32, 399-426. [CrossRef]

15. Brodie, R.J.; Hollebeek, L.D.; Jurić, B.; Ilić, A. Customer engagement: Conceptual domain, fundamental propositions, and implications for research. J. Serv. Res. 2011, 14, 252-271. [CrossRef]

16. Kumar, V.; Pansari, A. Competitive advantage through engagement. J. Market. Res. 2016, 53, 497-514. [CrossRef]

17. Venkatesan, R. Executing on a Customer Engagement Strategy; Springer: Berlin, Germany, 2017.

18. Lacey, R.; Kennett-Hensel, P.A.; Manolis, C. Is corporate social responsibility a motivator or hygiene factor? Insights into its bivalent nature. J. Acad. Market. Sci. 2015, 43, 315-332. [CrossRef]

19. Lii, Y.S.; Lee, M. Doing right leads to doing well: When the type of CSR and reputation interact to affect consumer evaluations of the firm. J. Bus. Ethics 2012, 105, 69-81. [CrossRef]

20. Salmones, M.D.M.G.D.L.; Crespo, A.H.; Bosque, I.R.D. Influence of Corporate Social Responsibility on Loyalty and Valuation of Services. J. Bus. Ethics 2005, 61, 369-385. [CrossRef]

21. Inoue, Y.; Kent, A. A conceptual framework for understanding the effects of corporate social marketing on consumer behavior. J. Bus. Ethics 2014, 121, 621-633. [CrossRef]

22. Romani, S.; Grappi, S.; Bagozzi, R.P. Explaining consumer reactions to corporate social responsibility: The role of gratitude and altruistic values. J. Bus. Ethics 2013, 114, 193-206. [CrossRef]

23. Marin, L.; Ruiz, S. "I need you too!" Corporate identity attractiveness for consumers and the role of social responsibility. J. Bus. Ethics 2007, 71, 245-260. [CrossRef]

24. Sen, S.; Bhattacharya, C.B. Does doing good always lead to doing better? Consumer reactions to corporate social responsibility. J. Market. Res. 2001, 38, 225-243. [CrossRef]

25. Eberle, D.; Berens, G.; Li, T. The impact of interactive corporate social responsibility communication on corporate reputation. J. Bus. Ethics 2013, 118, 731-746. [CrossRef]

26. Leckie, C.; Nyadzayo, M.W.; Johnson, L.W. Antecedents of consumer brand engagement and brand loyalty. J. Market. Manag. 2016, 32, 558-578. [CrossRef]

27. Dessart, L.; Veloutsou, C.; Morgan-Thomas, A. Consumer engagement in online brand communities: A social media perspective. J. Prod. Brand Manag. 2015, 24, 28-42. [CrossRef]

28. Harrigan, P.; Evers, U.; Miles, M.; Daly, T. Customer engagement with tourism social media brands. Tour. Manag. 2017, 59, 597-609. [CrossRef]

29. Algharabat, R.; Rana, N.P.; Dwivedi, Y.K.; Alalwan, A.A.; Qasem, Z. The effect of telepresence, social presence and involvement on consumer brand engagement: An empirical study of non-profit organizations. J. Retail. Consum. Serv. 2018, 40, 139-149. [CrossRef]

30. Hsieh, S.H.; Chang, A. The psychological mechanism of brand co-creation engagement. J. Interact. Market. 2016, 33, 13-26. [CrossRef]

31. Karaosmanoglu, E.; Altinigne, N.; Isiksal, D.G. CSR motivation and customer extra-role behavior: Moderation of ethical corporate identity. J. Bus. Res. 2016, 69, 4161-4167. [CrossRef]

32. Gallup, I. Customer Engagement, Turning Customers Into True Believers. Available online: https://www. gallup.com/services/169331/customer-engagement.aspx? (accessed on 4 November 2018).

33. Lichtenstein, D.R.; Drumwright, M.E.; Braig, B.M. The Effect of Corporate Social Responsibility on Customer Donations to Corporate-Supported Nonprofits. J. Market. 2004, 68, 16-32. [CrossRef]

34. Vlachos, P.A. Corporate social performance and consumer-retailer emotional attachment: The moderating role of individual traits. Eur. J. Market. 2012, 46, 1559-1580. [CrossRef] 
35. Xie, C.; Bagozzi, R.P.; Grønhaug, K. The role of moral emotions and individual differences in consumer responses to corporate green and non-green actions. J. Acad. Market. Sci. 2015, 43, 333-356. [CrossRef]

36. Carvalho, A.; Fernandes, T. Understanding Customer Brand Engagement With Virtual Social Communities: A Comprehensive Model Of Drivers, Outcomes And Moderators. J. Market. Theory Pract. 2018, 26, 23-37. [CrossRef]

37. Braun, C.; Hadwich, K.; Bruhn, M. How do different types of customer engagement affect important relationship marketing outcomes? An empirical analysis. J. Custom. Behav. 2017, 16, 111-144. [CrossRef]

38. Verleye, K.; Gemmel, P.; Rangarajan, D. Managing engagement behaviors in a network of customers and stakeholders: Evidence from the nursing home sector. J. Serv. Res. 2014, 17, 68-84. [CrossRef]

39. Jaakkola, E.; Alexander, M. The role of customer engagement behavior in value co-creation: A service system perspective. J. Serv. Res. 2014, 17, 247-261. [CrossRef]

40. Hollebeek, L.D.; Chen, T. Exploring positively- versus negatively-valenced brand engagement: A conceptual model. J. Prod. Brand Manag. 2014, 23, 62-74. [CrossRef]

41. Dwivedi, A. A higher-order model of consumer brand engagement and its impact on loyalty intentions. J. Retail. Consum. Serv. 2015, 24, 100-109. [CrossRef]

42. So, K.K.F.; King, C.; Sparks, B. Customer engagement with tourism brands: Scale development and validation. J. Hosp. Tour. Res. 2014, 38, 304-329. [CrossRef]

43. Vivek, S.D.; Beatty, S.E.; Morgan, R.M. Customer engagement: Exploring customer relationships beyond purchase. J. Market. Theory Pract. 2012, 20, 122-146. [CrossRef]

44. Hollebeek, L.D. Demystifying customer brand engagement: Exploring the loyalty nexus. J. Market. Manag. 2011, 27, 785-807. [CrossRef]

45. Sashi, C. Customer engagement, buyer-seller relationships, and social media. Manag. Decis. 2012, 50, $253-272$. [CrossRef]

46. Vargo, S.L.; Lusch, R.F. Service-dominant logic: Continuing the evolution. J. Acad. Market. Sci. 2008, 36, 1-10. [CrossRef]

47. So, K.K.F.; King, C.; Sparks, B.A.; Wang, Y. The role of customer engagement in building consumer loyalty to tourism brands. J. Travel Res. 2016, 55, 64-78. [CrossRef]

48. Brodie, R.J.; Ilic, A.; Juric, B.; Hollebeek, L. Consumer engagement in a virtual brand community: An exploratory analysis. J. Bus. Res. 2013, 66, 105-114. [CrossRef]

49. Calder, B.J.; Isaac, M.S.; Malthouse, E.C. How to capture consumer experiences: A context-specific approach to measuring engagement: Predicting consumer behavior across qualitatively different experiences. J. Adv. Res. 2016, 56, 39-52. [CrossRef]

50. Dahlsrud, A. How corporate social responsibility is defined: An analysis of 37 definitions. Corp. Soc. Resp. Environ. Manag. 2008, 15, 1-13. [CrossRef]

51. O'Higgins, E.R. Corporations, civil society, and stakeholders: An organizational conceptualization. J. Bus. Ethics 2010, 94, 157-176. [CrossRef]

52. Klein, J.; Dawar, N. Corporate social responsibility and consumers' attributions and brand evaluations in a product-harm crisis. Int. J. Res. Market. 2004, 21, 203-217. [CrossRef]

53. Sen, S.; Bhattacharya, C.B.; Korschun, D. The role of corporate social responsibility in strengthening multiple stakeholder relationships: A field experiment. J. Acad. Market. Sci. 2006, 34, 158-166. [CrossRef]

54. Marin, L.; Ruiz, S.; Rubio, A. The role of identity salience in the effects of corporate social responsibility on consumer behavior. J. Bus. Ethics 2009, 84, 65-78. [CrossRef]

55. Martínez, P.; del Bosque, I.R. CSR and customer loyalty: The roles of trust, customer identification with the company and satisfaction. Int. J. Hosp. Manag. 2013, 35, 89-99. [CrossRef]

56. Liu, W.; Aaker, J. The happiness of giving: The time-ask effect. J. Consum. Res. 2008, 35, 543-557. [CrossRef]

57. Chang, M.J.; Kang, J.H.; Ko, Y.J.; Connaughton, D.P. The effects of perceived team performance and social responsibility on pride and word-of-mouth recommendation. Sport Market. Q. 2017, 26, 31.

58. Pansari, A.; Kumar, V. Customer engagement: the construct, antecedents, and consequences. J. Acad. Market. Sci. 2017, 45, 294-311. [CrossRef]

59. Stets, J.E.; Burke, P.J. Identity theory and social identity theory. Soc. Psychol. Q. 2000, 63, 224-237. [CrossRef]

60. Hornsey, M.J. Social identity theory and self-categorization theory: A historical review. Soc. Personal. Psychol. Compass 2008, 2, 204-222. [CrossRef] 
61. Maignan, I.; Ferrell, O. Corporate social responsibility and marketing: An integrative framework. J. Acad. Market. Sci. 2004, 32, 3-19. [CrossRef]

62. Pivato, S.; Misani, N.; Tencati, A. The impact of corporate social responsibility on consumer trust: The case of organic food. Bus. Ethics A Eur. Rev. 2008, 17, 3-12. [CrossRef]

63. Morgan, R.M.; Hunt, S.D. The commitment-trust theory of relationship marketing. J. Market. 1994, 58, $20-38$. [CrossRef]

64. Edvardsson, B.; Johnson, M.D.; Gustafsson, A.; Strandvik, T. The effects of satisfaction and loyalty on profits and growth: Products versus services. Total Qual. Manag. 2000, 11, 917-927. [CrossRef]

65. Flavián, C.; Guinalíu, M.; Gurrea, R. The role played by perceived usability, satisfaction and consumer trust on website loyalty. Inf. Manag. 2006, 43, 1-14. [CrossRef]

66. Hapsari, R.; Clemes, M.D.; Dean, D. The impact of service quality, customer engagement and selected marketing constructs on airline passenger loyalty. Int. J. Qual. Serv. Sci. 2017, 9, 21-40. [CrossRef]

67. Wirtz, J.; Den Ambtman, A.; Bloemer, J.; Horváth, C.; Ramaseshan, B.; Van De Klundert, J.; Gurhan Canli, Z.; Kandampully, J. Managing brands and customer engagement in online brand communities. J. Serv. Manag. 2013, 24, 223-244. [CrossRef]

68. Islam, J.U.; Rahman, Z. Linking customer engagement to trust and word-of-mouth on Facebook brand communities: An empirical study. J. Int. Commer. 2016, 15, 40-58. [CrossRef]

69. Vivek, S.D.; Beatty, S.E.; Dalela, V.; Morgan, R.M. A generalized multidimensional scale for measuring customer engagement. J. Market. Theory Pract. 2014, 22, 401-420. [CrossRef]

70. Osei-Frimpong, K.; McLean, G. Examining online social brand engagement: A social presence theory perspective. Technol. Forecast. Soc. Chang. 2018, 128, 10-21. [CrossRef]

71. Celuch, K.; Robinson, N.M.; Walsh, A.M. A framework for encouraging retail customer feedback. J. Serv. Market. 2015, 29, 280-292. [CrossRef]

72. Wirtz, J.; Kuan Tambyah, S.; Mattila, A.S. Organizational learning from customer feedback received by service employees: A social capital perspective. J. Serv. Manag. 2010, 21, 363-387. [CrossRef]

73. Babbar, S.; Koufteros, X. The human element in airline service quality: contact personnel and the customer. Int. J. Oper. Prod. Manag. 2008, 28, 804-830. [CrossRef]

74. Lusch, R.F.; Vargo, S.L.; O’brien, M. Competing through service: Insights from service-dominant logic. J. Retail. 2007, 83, 5-18. [CrossRef]

75. Voss, C.A.; Roth, A.V.; Rosenzweig, E.D.; Blackmon, K.; Chase, R.B. A tale of two countries' conservatism, service quality, and feedback on customer satisfaction. J. Serv. Res. 2004, 6, 212-230. [CrossRef]

76. Stanaland, A.J.; Lwin, M.O.; Murphy, P.E. Consumer perceptions of the antecedents and consequences of corporate social responsibility. J. Bus. Ethics 2011, 102, 47-55. [CrossRef]

77. Brown, T.J.; Barry, T.E.; Dacin, P.A.; Gunst, R.F. Spreading the word: Investigating antecedents of consumers' positive word-of-mouth intentions and behaviors in a retailing context. J. Acad. Market. Sci. 2005, 33, 123-138. [CrossRef]

78. Hair, J.; Black, W.C.; Babin, B.J.; Anderson, R.E. Multivariate data analysis, a global perspective. N. J. Pearson Ed. 2010, 7, 816.

79. Diamantopoulos, A.; Siguaw, J.A. Introducing LISREL: A Guide for the Uninitiated; Sage: Saunders Oaks, CA, USA, 2013.

80. Fornell, C.; Larcker, D.F. Evaluating structural equation models with unobservable variables and measurement error. J. Market. Res. 1981, 18, 39-50. [CrossRef]

81. Bhattacharya, C.B.; Korschun, D.; Sen, S. Strengthening stakeholder-company relationships through mutually beneficial corporate social responsibility initiatives. J. Bus. Ethics 2009, 85, 257-272. [CrossRef]

82. Park, J.; Lee, H.; Kim, C. Corporate social responsibilities, consumer trust and corporate reputation: South Korean consumers' perspectives. J. Bus. Res. 2014, 67, 295-302. [CrossRef]

(C) 2018 by the authors. Licensee MDPI, Basel, Switzerland. This article is an open access article distributed under the terms and conditions of the Creative Commons Attribution (CC BY) license (http:/ / creativecommons.org/licenses/by/4.0/). 